\title{
KEBIJAKAN UPAH MINIMUM UNTUK PEREKONOMIAN YANG BERKEADILAN: TINJAUAN UUD 1945
}

\author{
Devanto Shasta Pratomo \\ Putu Mahardika Adi Saputra \\ Fakultas Ekonomi \& Bisnis Universitas Brawijaya
}

\begin{abstract}
The aim of this research is to determine the progress of minimum wage policy in Indonesia, and their linkage to the 1945 Constitution article 27 act 2. The implementation of minimum wage policy in accordance with that constitution, at least should be a few things to do. This includes needs such as decent living as a component of minimum wage determination. Furthermore, it needs to fill the necessity of transparent effort and intense socialization of benefit provision in the minimum wage. In addition it must be clear about the protected status of workers in minimum wage policy. The last is the enforcement and strict penalties for companies that do not apply the appropriate minimum wage policy.
\end{abstract}

Keywords: 1945 Constitution article 27 act 2, Minimum Wage Policy, Enfrocement,

\section{A. LATAR BELAKANG}

Kebijakan Upah Minimum telah menjadi isu yang penting dalam masalah ketenagakerjaan di beberapa negara baik maju maupun berkembang. Sasaran dari kebijakan upah minimum ini adalah untuk menutupi kebutuhan hidup minimum dari pekerja dan keluarganya. Dengan demikian, kebijakan upah minimum adalah untuk (a) menjamin penghasilan pekerja sehingga tidak lebih rendah dari suatu tingkat tertentu, (b) meningkatkan produktivitas pekerja, (c) mengembangkan dan meningkatkan perusahaan dengan cara-cara produksi yang lebih efisien (Sumarsono, 2003).

Kebijakan upah minimum di Indonesia sendiri pertama kali diterapkan pada awal tahun 1970an. Meskipun demikian, pelaksanaannya tidak efektif pada tahun-tahun tersebut (Suryahadi $\mathrm{dkk}$, 2003). Pemerintah Indonesia baru mulai memberikan perhatian lebih terhadap pelaksanaan kebijakan upah minimum pada akhir tahun 1980an. Hal ini terutama disebabkan adanya tekanan dari dunia internasional sehubungan dengan isu-isu tentang pelanggaran standar ketenagakerjaan yang terjadi di Indonesia. Di masa tersebut, sebuah organisasi perdagangan Amerika Serikat (AFL-CIO) dan beberapa aktivis hak asasi manusia mengajukan keberatan terhadap sebuah perusahaan multinasional Amerika Serikat beroperasi di Indonesia yang diduga memberikan upah yang sangat rendah dan kondisi lingkungan pekerjaan yang berada dibawah standar (Gall, 1998 dan Suryahadi dkk 2003). Sebagai hasilnya, kondisi ini memaksa pemerintah Indonesia pada waktu itu untuk memberikan perhatian lebih terhadap kebijakan upah minimumnya dengan menaikkan upah minimum sampai dengan tiga kali lipat dalam nilai nominalnya (dua kali lipat dalam nilai riil). 
Pada awalnya kebijakan upah minimum ditetapkan berdasarkan besaran biaya Kebutuhan Fisik Minimum (KFM). Dalam perkembangannya kemudian, dalam era otonomi daerah, dalam menentukan besaran tingkat upah minimum beberapa pertimbangannya adalah: (a) biaya Kebutuhan Hidup Minimum (KHM), (b) Indeks Harga Konsumen (IHK), (c) tingkat upah minimum antar daerah, (d) kemampuan, pertumbuhan, dan keberlangsungan perusahaan, (e) kondisi pasar kerja, dan (f) pertumbuhan ekonomi dan pendapatan per kapita.

Dengan berbagai kondisi empiris dan penjelasan tentang implementasi dari kebijakan upah minimum diatas, sebenarnya segala produk hukum termasuk kebijakannya tidak boleh melenceng dari prinsip dasar hukum yaitu Undang-Undang Dasar 1945. Demikian pula dengan kebijakan upah minimum harus mengacu pada UUD tersebut yang secara jelas dalam UUD 1945 pasal 27 ayat 2 dikatakan bahwa setiap orang berhak mendapatkan pekerjaan dan penghidupan yang layak. Pekerjaan dan penghidupan yang layak tersebutlah yang seharusnya dijadikan standar baku bagi penetapan upah minimum. Meskipun demikian, disamping penghidupan yang layak bagi pekerja beberapa perhitungan perlu dilakukan dalam menentukan tingkat upah minimum, seperti misalnya menjaga produktivitas usaha dan keberlanjutan kondisi ekonomi nasional (dan daerah) (Hendrani, 2002).

Dengan kata lain, kebijakan upah minimum harus ditetapkan untuk meningkatkan kehidupan yang layak khususnya bagi para pekerja tetapi juga tanpa merugikan kelangsungan hidup perusahaan yang bisa mengancam keberlanjutan kondisi ekonomi dan produktivitas nasional (dan daerah). Penelitian ini mengkaji sejauh mana kebijakan upah minimum berusaha memenuhi kedua kepentingan tersebut tetapi tetap sesuai dengan UUD 1945 khususnya pasal 27. Oleh karena itu berdasarkan uraian di atas, permasalahan yang diangkat dalam penelitian ini adalah sebagai berikut: 1). Bagaimana perkembangan dari pelaksanaan kebijakan Upah Minimum di Indonesia dan 2). Bagaimana pelaksanaan kebijakan upah minimum dikaitkan dengan UUD 1945 pasal 27 ayat 2 ?

\section{B. KAJIAN TEORITIS}

\section{Tinjauan Kebijakan Upah Minimum}

Upah Minimum adalah suatu penerimaan bulanan minimum (terendah) sebagai imbalan dari pengusaha kepada karyawan untuk suatu pekerjaan atau jasa yang telah atau akan dilakukan dan dinyatakan atau dinilai dalam bentuk uang yang ditetapkan atas dasar suatu persetujuan atau peraturan perundang-undangan serta dibayarkan atas dasar suatu perjanjian kerja antara pengusaha dengan karyawan termasuk tunjangan, baik karyawan itu sendiri maupun untuk keluarganya. Sebagaimana yang telah diatur dalam PP No. 8/1981 upah minimum dapat ditetapkan secara minimum regional, sektoral regional maupun subsektoral, meskipun saat ini baru upah minimum regional yang dimiliki oleh setiap daerah. Dalam hal ini upah minimum adalah terdiri dari upah pokok dan tunjangan tetap. Namun dalam peraturan pemerintah yang diatur secara jelas hanya upah pokoknya saja dan tidak termasuk tunjangan, sehingga seringkali menimbulkan kontroversi bagi pengusaha dan pekerja. Tunjangan tetap sendiri adalah tunjangan yang diberikan secara tetap tanpa melihat tingkat kehadiran pekerja ataupun output, seperi 
misalnya tunjangan keluarga tetap dan tunjangan yang berdasar pada senioritas.

Menurut Undang Undang No 13 tahun 2003 disebutkan bahwa upah minimum hanya ditujukan bagi pekerja dengan masa kerja 0 (nol) sampai dengan 1 (satu) tahun. Dari definisi tersebut, terdapat dua unsur penting dari upah minimum (Sumarsono, 2003) yaitu adalah:

a) Upah permulaan adalah upah terendah yang harus diterima oleh buruh pada waktu pertama kali dia diterima bekerja.

b) Jumlah upah minimum haruslah dapat memenuhi kebutuhan hidup buruh secara minimal yaitu kebutuhan untuk sandang, pangan dan keperluan rumah tangga.

Sumarsono (2003) mengemukakan pula bahwa upah merupakan sumber utama penghasilan seorang pekerja, sehingga upah harus cukup memenuhi kebutuhan pekerja dan keluarganya dengan wajar. Batas kewajaran tersebut dalam Kebijakan Upah Minimum di Indonesia dapat dinilai dan diukur dengan kebutuhan hidup minimum (KHM) atau seringkali saat ini disebut dengan Kebutuhan Hidup Layak (KHL).

Namun kenyataannya justru menunjukkan bahwa hanya sedikit perusaha yang secara sadar dan sukarela terus menerus berusaha meningkatkan penghidupan karyawannya, terutama pekerja golongan yang paling rendah. Di pihak lain, karyawan melalui serikat pekerja dan/atau dengan mengundang pemerintah selalu menuntut kenaikan upah. Tuntutan seperti itu yang tidak disertai dengan peningkatan produktivitas kerja akan mendorong pengusaha untuk : (a) mengurangi penggunaan tenaga kerja dengan menurunkan produksi ; (b) menggunakan teknologi yang lebih padat modal; dan/atau (c) menaikkan harga jual barang yang kemudian justru akan mendorong inflasi (Sumarsono, 2003).

\section{Prinsip-Prinsip Dalam Penetapan Kebijakan Upah Minimum di Indonesia}

Menurut Peraturan Menteri Tenaga Kerja No. 01/MEN/1999, paling tidak ada sepuluh prinsip-prinsip yang harus ditaati dalam penetapan kebijakan upah minimum di Indonesia.

(1) Upah minimum adalah upah bulanan terendah yang terdiri dari upah pokok dan tunjangan tetap.

(2) Upah minimum wajib dibayar kepada bekerja secara bulanan atau dengan kesepakatan antara pekerja dan pengusaha misalnya untuk upah mingguan atau upah dua mingguan.

(3) Besarnya upah pekerja yang berstatus tetap, tidak tetap, atau dalam masa percobaan adalah serendah-rendahnya sebesar upah minimum.

(4) Upah minimum hanya berlaku untuk pekerja yang bekerja dibawah satu tahun.

(5) Peninjauan upah dilakukan atas kesepakatan antara pekerja/serikat pekerja dan pengusaha.

(6) Pekerja dengan sistem borongan atau dengan satuan hasil serendah rendahnya adalah sebesar upah minimum untuk upah bulanannya.

(7) Upah pekerja harian lepas ditetapkan secara bulanan berdasar hari kehadiran (dengan pro rata basis).

(8) Perusahaan yang telah memberikan upah diatas upah minimum tidak diperbolehkan menurunkan upah.

(9) Dengan kenaikan upah minimum, pekerja diwajibkan untuk memelihara prestasi kerja (produktivitas) yang ukurannya dirumuskan bersama antara pekerja dan pengusaha. 
(10) Pengusaha yang tidak mampu menerapkan kebijakan upah minimum untuk pekerja diijinkan untuk melakukan penangguhan sementara kepada pemerintah atau pejabat yang ditunjuk.

Selanjutnya dengan adanya otonomi daerah pemerintah mengatur kebijakan ketenagakerjaannya, termasuk didalamnya kebijakan upah minimum di dalam Undang Undang No 13 tahun 2003 tentang Ketenagakerjaan yang isinya antara lain:

(1) Pemerintah menetapkan upah berdasarkan kebutuhan hidup layak(KHL) dan dengan memperhatikan produktivitas dan pertumbuhan ekonomi. Sehingga Upah minimum diarahkan kepada pencapaian kebutuhan hidup layak.

(2) Upah Minimum dapat diterapkan: (a) berdasarkan wilayah provinsi atau kabupaten/kota; (b) berdasarkan sektor pada wilayah provinsi atau kabupaten/kota. Upah minimum sektoral dapat ditetapkan untuk kelompok lapangan usaha beserta pembagiannya menurut klasifikasi lapangan usaha Indonesia untuk kabupaten/kota, provinsi, beberapa provinsi atau nasional dan tidak boleh lebih rendah dari upah minimum regional daerah yang bersangkutan.

(3) Upah minimum ditetapkan oleh Gubernur dengan memperhatikan rekomendasi dari Dewan Pengupahan Provinsi dan/atau Bupati/Walikota.

(4) Pengusaha dilarang membayar upah lebih rendah dari upah minimum.Bagi pengusaha yang tidak mampu membayar upah minimum dapat dilakukan penangguhan. Penangguhan pelaksanaan upah minimum bagi perusahaan yang tidak mampu dimaksudkan untuk membebaskan perusahaan yang bersangkutan melaksanakan upah minimum yang berlaku dalam kurun waktu tertentu. Apabila penangguhan tersebut berakhir maka perusahaan yang bersangkutan wajib melaksanakan upah minimum yang berlaku pada saat itu tetapi tidak wajib membayar pemenuhan ketentuan upah minimum yang berlaku pada waktu diberikan penangguhan.

\section{Teori Ekonomi Tentang Dampak Kebijakan Upah Minimum}

\section{Pasar Kompetitif}

Dalam konteks pasar tenaga kerja kompetitif atau persaingan sempurna, pengusaha dan tenaga kerja dapat dengan bebas masuk dan keluar dari pasar kerja, sehingga alokasi tenaga kerja dapat terjadi pada suatu ekuilibrium yang efisien. Dalam pasar ini, dengan menggunakan pendekatan maksimisasi profit, pengusaha akan mempekerjakan karyawannya sampai marginal cost mereka sama dengan marginal revenue product of labour. 


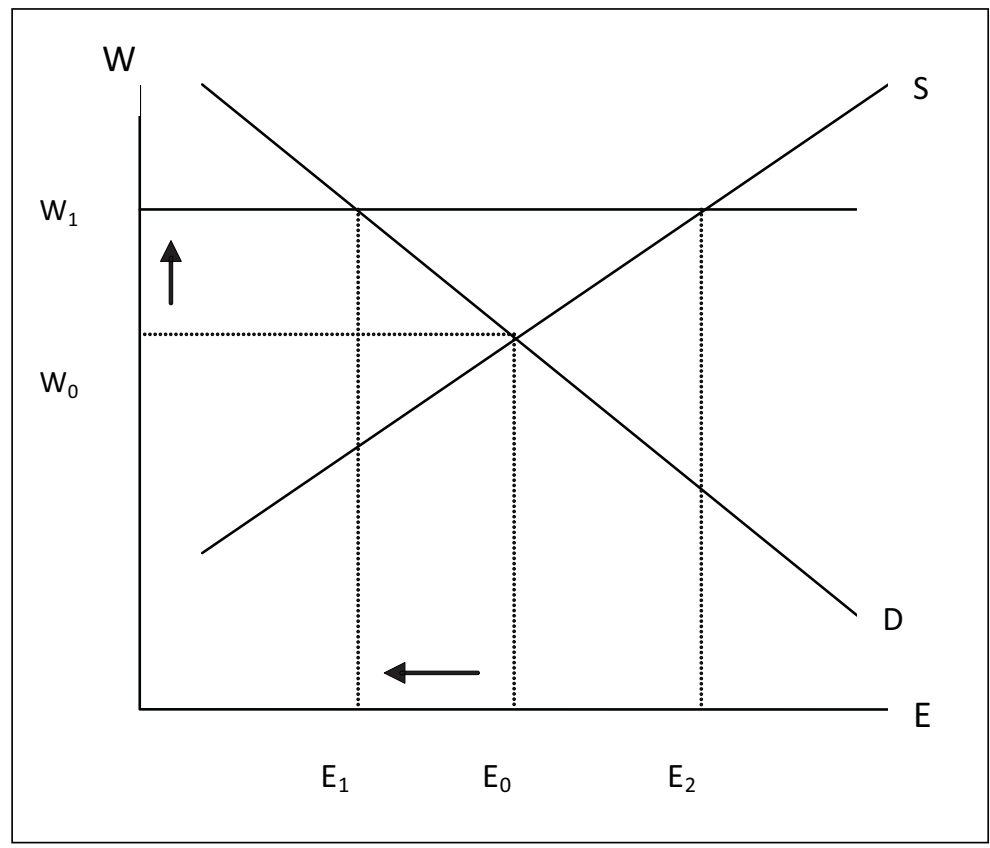

Gambar 1 Upah Minimum di Pasar Kompetitif Sumber:

Gambar 1 menunjukkan kondisi keseimbangan harga dan tenaga kerja dilihat dari model kompetitif. Kurva permintaan tenaga kerja digambarkan menurun (downward sloping) menunjukkan marginal revenue product of labour $(M R P)$. MRP yang menurun ini menunjukkan bahwa kontribusi terhadap output (produktivitas) akan meningkat pada tingkat yang lambat laun menurun (diminishing rate) ketika tenaga kerja ditambah. Di sisi lain, kurva penawaran tenaga kerja adalah menaik (upward sloping) menggambarkan alternatif-alternatif penerimaan yang diterima oleh pekerja. Tingkat keseimbangan dari tingkat upah dan tenaga kerja ditunjukkan oleh pertemuan antara kurva permintaan (D) dan kurva penawaran (S). Seperti yang ditunjukkan oleh gambar 1, tingkat upah keseimbangan adalah $\mathrm{W}_{0}$, sedangkan $\mathrm{E}_{0}$ keseimbangan tenaga kerja.

Seandainya upah minimum berada di atas tingkat keseimbangan $\mathrm{W}_{1}$, kondisi ini akan menciptakan kelebihan penawaran tenaga kerja (excess supply of labour) menggambarkan bahwa hanya $E_{1}$ yang akan dipekerjakan dengan jumlah pekerja yang tersedia sebesar $E_{2}$. 
Kelebihan penawaran ini menyebabkan turunnya tenaga kerja yang akan dipekerjakan dari $\mathrm{E}_{0}$ (tingkat keseimbangan) ke $\mathrm{E}_{1}$. $\mathrm{E}_{1}$ secara otomatis menunjukkan tingkat keseimbangan yang baru setelah adanya kebijakan upah minimum di dalam pasar kompetitif.

Di daerah atau negara yang mana kebijakan upah minimum diterapkan secara penuh, maka kelebihan penawaran ini bisa digambarkan dengan meningkatnya tingkat pengangguran. Tetapi untuk negara yang sedang berkembang, dimana tidak tersedianya social benefit bagi penganggur dan juga cukup besarnya sektor informal maka kondisi kelebihan penawaran tenaga kerja ini tidak selalu menunjukkan pengangguran yang meningkat, tetapi berpindahnya pekerja dari sector formal (yang terkover oleh kebijakan upah minimum) ke sektor informal (yang tidak terkover oleh kebijakan upah minimum). Secara lengkap kondisi ini digambarkan oleh model dual sektor berikut ini.

\section{Model Dual Sektor}

Model dual sektor, dimana dikembangkan oleh Welch (1974) adalah perluasan dari model kompetitif. Model ini mengasumsikan bahwa terdapat dua sector di dalam ekonomi (segmentasi ekonomi) yaitu sector formal (yang terkover oleh kebijakan upah minimum) dan sector informal (sector yang tidak terkover oleh kebijakan upah minimum) dengan mobilitas yang sempurna antar dua sector tersebut. Sebelum adanya kebijakan upah minimum kedua sector ini diasumsikan menerima upah pada tingkat yang sama yaitu $\mathrm{W}_{0}$.

Penetapan upah minimum akan mengurangi permintaan tenaga kerja di sektor formal. Kelebihan penawaran tenaga kerja ini akan diserap oleh sektor informal yang tingkat upahnya tidak diatur oleh regulasi, yang pada gilirannya akan mengurangi tingkat upah. Jika pangsa kerja di sektor informal lebih rendah, maka dampak distribusi pendapatannya akan justru memburuk (Sumarsono, 2009). ILO menambahkan bahwa sektor informal adalah bagian dari ekonomi pasar yang memproduksi secara legal barang dan jasa untuk dijual dan mendapatkan penghasilan. Sektor ini meliputi tenaga kerja yang terdapat di dalamnya, baik yang terdapat pada perusahaan informal (usaha kecil yang tidak terdaftar secara resmi) dan diluar dari itu. Wirausaha informal dan pekerja sektor ini memiliki karakter penting, yaitu tidak dikenali dan tidak dilindungi oleh ketentuan upah minimum dan peraturan ketenagakerjaan. 


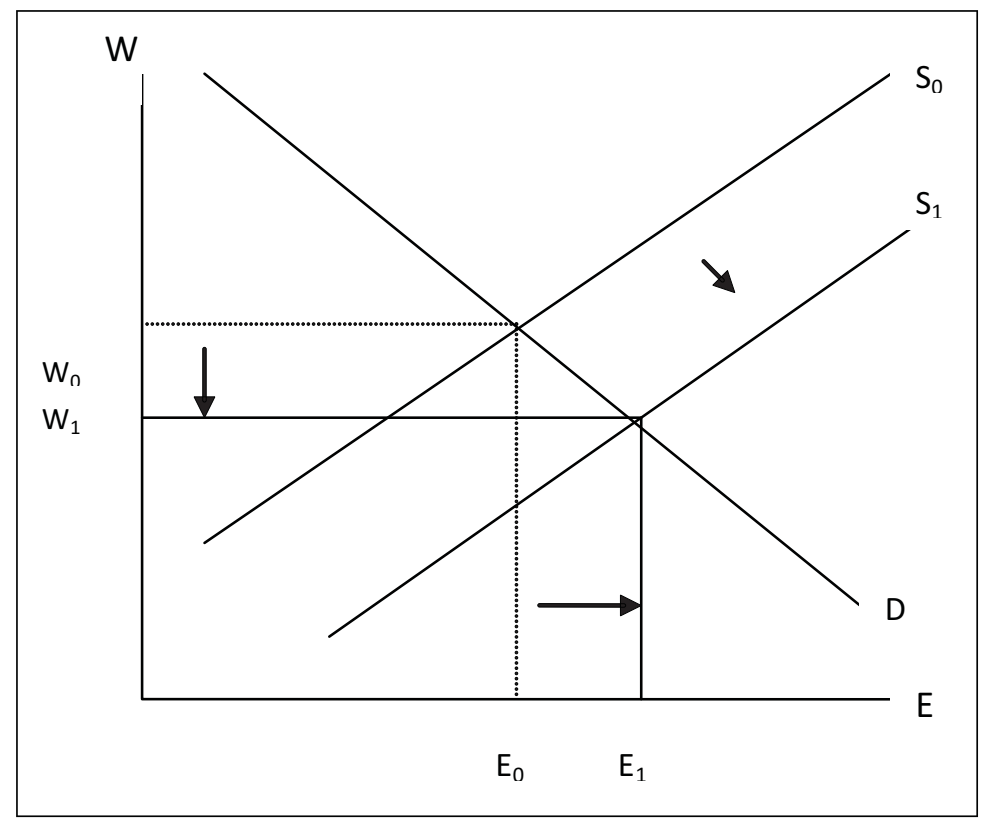

Gambar 2. Upah Minimum di Sektor Informal Sumber:

Seandainya kemudian ada kebijakan upah minimum pada sektor formal yang lebih tinggi dibandingkan tingkat keseimbangan upah $\mathrm{W}_{0}$. Hal ini akan menyebabkan sector formal menjadi lebih dipilih oleh pekerja dibandingkan sector informal. Dengan kata lain kebijakan upah minimum ini menyebabkan kelebihan penawaran tenaga kerja (excess supply of labour) pada sector formal. Berdasarkan model dual sector ini kelebihan penawaran pada sector formal akan menyebabkan pergeseran tenaga kerja dari sector formal ke sector informal. Kondisi ini digambarkan oleh pergeseran dari kurva penawaran dari sector informal dari $\mathrm{S}_{0}$ ke $\mathrm{S}_{1}$ pada gambar 2 .

Pada kenyataannya pergeseran tenaga kerja juga dimungkinkan dari pasar informal menuju pasar formal, hal ini terjadi bilamana di pasar formal tercipta kesempatan kerja kembali sehingga mengundang pekerja di pasar informal untuk mendapatkan upah yang lebih baik. Hal tersebut menyebabkan terjadinya pergeseran kurva penawaran tenaga kerja di pasar informal menjadi $\mathrm{S}_{0}$ sehingga tingkat upah di pasar informal mengalami kenaikan. Pada kenyataannya seorang tenaga kerja dapat dengan mudah berpindah dari satu sektor ke sektor yang lain karena terciptanya kesempatan kerja dan tingkat upah yang lebih baik. Perpindahan tenaga kerja antar sektoral tersebut akan berhenti bila tingkat upah yang diharapkan (expected wage) antar sektor tersebut sama. 


\section{Model Monopsony}

Model monopsoni mengasumsikan bahwa hanya ada sebuah perusahaan yang mendominasi di pasar kerja, sehingga pengusaha memiliki kekuatan untuk menentukan tingkat upah yang akan memaksimalkan keuntungannya (monopsony power). Kenaikan tingkat upah yang dibayarkan kepada pekerja dalam hal ini akan menjadi daya tarik bagi calon pekerja atau meningkatkan penawaran tenaga kerja. Sebelum adanya upah minimum, marginal revenue product of labour $\left(\mathrm{MRP}_{\mathrm{L}}\right)$ adalah memiliki slope yang menurun ke bawah (downward sloping) menggambarkan tambahan penerimaan sebagai akibat dari penambahan jumlah tenaga kerja. Sedangkan kurva penawaran tenaga kerja (S) memiliki slope yang menaik karena seorang monopsonis harus membayar upah lebih tinggi untuk menarik atau menambah jumlah tenaga kerja yang dipekerjakannya. Kurva $\mathrm{S}$ juga menggambarkan biaya rata rata $\left(\mathrm{AC}_{\mathrm{L}}\right)$ yang menunjukkan tingkat upah rata-rata yang harus dibayarkan ketika pengusaha atau monopsonis akan mempekerjakan tambahan tenaga kerja. Tidak seperti dalam pasar kompetitif, marginal cost of labour $\left(\mathrm{MC}_{\mathrm{L}}\right)$ adalah lebih tinggi daripada $\mathrm{AC}_{\mathrm{L}}$ karena pengusaha membayar upah yang lebih tinggi ini tidak hanya kepada pekerja baru tetapi juga kepada pekerja yang sudah lama bekerja pada perusahaan itu. Dalam hal ini pengusaha akan mempekerjakan pekerja sampai dengan ketika $\mathrm{MC}_{\mathrm{L}}$ sama dengan $\mathrm{MRP}_{\mathrm{L}}$. Seperti yang tergambar pada gambar 2.3, pengusaha akan mendapatkan keuntungan maksimum ketika kurva $\mathrm{MC}_{\mathrm{L}}$ memotong kurva MRP. Tingkat upah keseimbangan adalah pada upah sebesar $\mathrm{W}_{0}$ dan tingkat tenaga kerja sebesar $\mathrm{E}_{0}$.

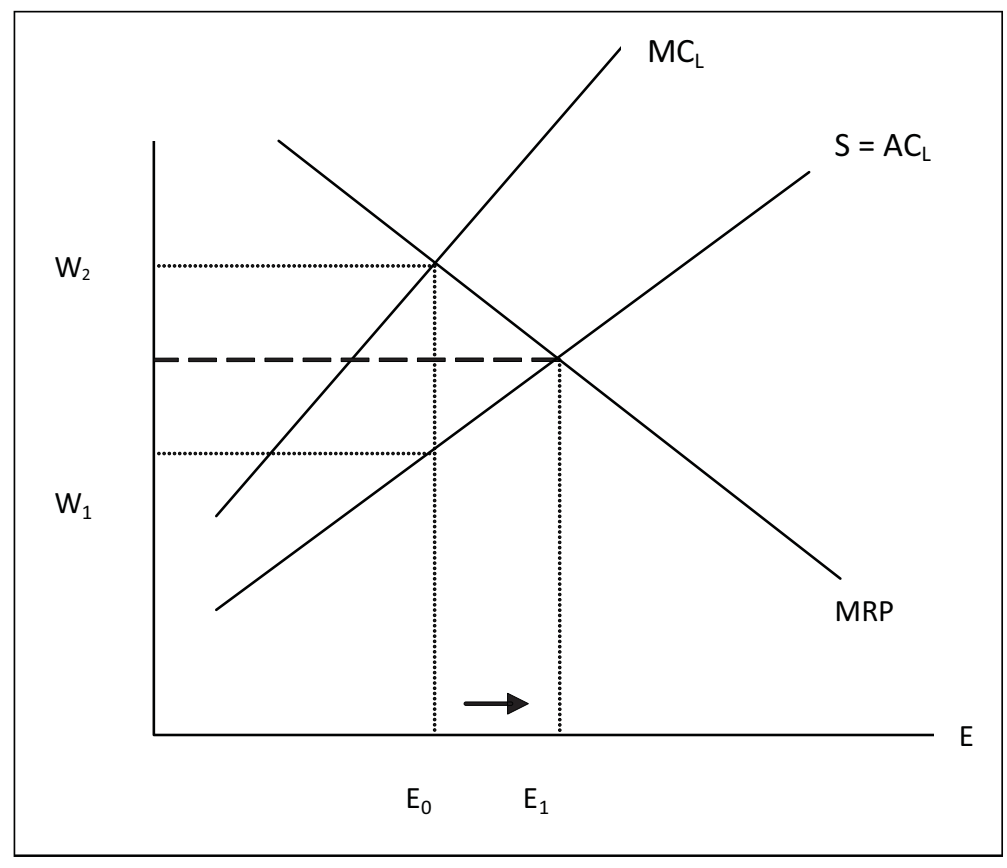

Gambar 3. Upah Minimum di Pasar Monopsoni

Sumber: 
Apabila ada kenaikan upah minimum misalkan pada $\mathrm{W}_{1}$ dimana lebih tinggi dibandingkan tingkat upah keseimbangan, maka marginal cost of labour (dan juga kurva penawaran tenaga kerja) adalah horizontal pada tingkat $\mathrm{W}_{1}$ dikarenakan mempekerjakan tambahan pekerja tidak selalu mensyaratkan tambahan tingkat upah sepanjang pekerja bersedia untuk dibayar lebih rendah atau paling tidak sebesar upah minimum. Kondisi ini berlangsung sampai kurva ini memotong kurva $\mathrm{S}$ yang asli. Setelah kurva $\mathrm{MC}_{\mathrm{L}}$ memotong kurva penawaran tenaga kerja yang asli, $\mathrm{S}$ akan memiliki slope yang menaik (mengikuti kurva $\mathrm{S}$ yang asli) menunjukkan bahwa pengusaha harus membayar diatas upah minimum jika mereka akan mempekerjakan tambahan pekerja. Dengan kata lain, kurva S adalah patah (kinked) ketika jumlah tenaga kerja adalah sebesar $\mathrm{E}_{1}$. Tingkat keseimbangan yang baru setelah upah minimum adalah menjadi $\mathrm{E}_{1}$ dan $\mathrm{W}_{1}$ dimana $\mathrm{MC}$ bertemu dengan $\mathrm{MRP}_{\mathrm{L}}$. Sebagai hasilnya, berbeda dengan model kompetitif, kenaikan upah minimum dapat meningkatkan jumlah tenaga kerja dari $\mathrm{E}_{0} \mathrm{ke}_{1}$ di dalam model monopsoni.

\section{METODE PENELITIAN DAN ANALISIS DATA}

\section{Ruang Lingkup dan Fokus Penelitian}

Ruang lingkup penelitian ini meliputi bagaimana perkembangan pelaksanaan kebijakan upah minimum di Indonesia dan bagaimana pelaksanaan kebijakan upah minimum di Indonesia apabila dikaitkan dengan UUD 1945 khususnya pasal 27. Sehingga fokus yang diteliti adalah proses pelaksanaan kebijakan upah minimum di Indonesia meliputi komponen penghitungan upah minimum di daerah, peran dan kepentingan stakeholders (tripartite: pengusaha, pekerja, dan pemerintah) dalam penetapan kebijakan upah minimum, dan kendala yang dihadapi dalam pelaksanaan kebijakan upah minimum. Fokus penelitian ini kemudian akan dikaitkan dengan khususnya pasal 27 UUD 45 bahwa setiap warga negara berhak atas penghidupan yang layak.

\section{Metode Analisis}

Dalam upaya menganalisis kebijakan upah minimum dalam perspektif konstitusi, peneliti menggunakan metode penelitian eksploratif. Jenis penelitian ini berusaha mencari ide-ide atau hubungan-hubungan yang baru. Metode ini sangat fleksibel dalam pencarian gagasan dan ide serta petunjuk mengenai kondisi dan situasi yang berkaitan dengan permasalahan yang dikaji sehingga dapat memformulasikan kebijakan atau strategi yang tepat.

Adapun langkah pertama yang perlu dilakukan adalah mengumpulkan semua literatur maupun kajian-kajian mengenai ketenagakerjaan dan kebijakan upah minimum, termasuk didalamnya mengumpulkan data-data sekunder baik berupa data BPS dan Departemen tenaga Kerja, Peraturan, Undang-Undang dan keputusan Menteri tentang kebijakan upah minimum. Selanjutnya dari sini diidentifikasi permasalahan mulai dari gejala sampai masalah yang mendasar.

Setelah proses identifikasi selanjutnya peneliti akan mengklasifikasikan masalah dan merekonstruksi kebijakan upah minimum dalam perspektif konstitusi. Selain itu, peneliti akan melakukan Focus Group Discussion kepada beberapa pakar yang ahli dalam kebijakan upah minimum. 


\section{HASIL DAN PEMBAHASAN}

\section{Perkembangan Pelaksanaan Kebijakan Upah Minimum di Indonesia}

\section{Upah Minimum di Indonesia Sebelum Otonomi Daerah}

Kebijakan upah minimum di Indonesia pertama kali diperkenalkan pada awal tahun 1970an (Rama, 2001 dan Suryahadi dkk, 2003). Meskipun sudah memiliki sejarah yang cukup panjang, implementasi dari kebijakan upah minimum ini tidak begitu efektif pada awal-awal pelaksanaan. Dalam periode tersebut upah minimum ditetapkan jauh berada dibawah tingkat keseimbangan upah menunjukkan bahwa upah minimum tidak mengikat bagi sebagian besar pekerja (Sugiyarto dan Endriga, 2008). Lebih lanjut, Sugiyarto dan Endriga (2008) menegaskan bahwa upah minimum di Indonesia relatif tidak dipaksakan dan digunakan hanya sebagai tujuan yang bersifat simbolis.

Kebijakan upah minimum mulai digunakan sebagai instrument yang penting bagi kebijakan pasar tenaga kerja oleh pemerintah Indonesia pada akhir tahun 1980an. Hal ini berawal dari adanya tekanan internasional sehubungan dengan pelanggaran terhadap standart kerja Internasional di Indonesia pada saat itu, secara khusus pada sector-sektor usaha yang berorientasi ekspor (Rama, 2001 dan Suryahadi dkk, 2003). Secara lebih spesifik, sebuah perusahaan multinasional terkenal milik Amerika Serikat yang beroperasi di Indonesia pada waktu itu diprotes oleh sebuah organisasi persatuan perdagangan Amerika Serikat (AFL-CIO) dan juga oleh beberapa aktivis hak asasi manusia internasional akibat penetapan upah yang rendah dan kondisi kerja yang buruk (Gall, 1998). Dalam kasus ini, tekanan internasional telah memaksakan untuk terciptanya sebuah klausa sosial yang disebut juga dengan General Scheme Preferences (GSP) yang mana berisi penolakan atas produk dari negara yang sedang berkembang, termasuk Indonesia, dimana standar kerjanya masih berada di bawah standar yang diakui secara internasional.

Dalam prakteknya, kondisi ini memaksa pemerintah Indonesia untuk mau tidak mau menjadi lebih perhatian terhadap kebijakan ketenagakerjaan mereka, termasuk didalamnya kebijakan upah minimum. Hal ini dilakukan dengan cara menaikkan upah minimum tiga kali lipat secara nominal (atau dua kali lipat secara riil) pada akhir tahun 1980an agar sejalan dengan biaya Kebutuhan Fisik Minimum (KFM). KFM sendiri diukur oleh biaya dari paket konsumsi minimum, termasuk didalamnya makanan, perumahan, pakaian, dan beberapa jenis barang yang lain untuk pekerja lajang dalam satu bulan (Sukatrilaksana, 2002).

Adapun Kebutuhan Fisik Minimum seorang pekerja dihitung dari kebutuhan minimum pekerja untuk kalori, protein, vitamin dan mineral lainnya. Dengan kata lain KFM adalah kebutuhan minimum pekerja yang dibutuhkan selama satu bulan berkaitan dengan kondisi fisiknya dalam melakukan pekerjaan. Secara rinci kebutuhan fisik minimum pekerja adalah sebagai berikut:

1) KFM untuk Pekerja Lajang, yaitu 2600 kalori per hari.

2) KFM (K-0) untuk Pekerja dengan istri tanpa anak, yaitu 4800 kalori per hari.

3) KFM (K-1) untuk Pekerja dengan istri dan satu orang anak yaitu 6700 kalori per hari.

4) KFM (K-2) untuk Pekerja dengan istri dan dua orang anak yaitu 8100 kalori per hari.

5) KFM (K-3) untuk Pekerja dengan istri dan tiga orang anak yaitu 10.000 kalori per hari. 
Adapun rumus perhitungan nilai KFM adalah sebagai berikut (Sumarsono, 2003):

$$
K F M=\sum_{t=1}^{n} \text { Pti.Qot }
$$

Keterangan :

$\mathrm{n} \mathrm{tPQ}==$ Banyaknya jenis atau macam barang dan jasa yang dibutuhkan dalam waktu satu bulan. Pekerja lajang membutuhkan 47 macam brang dan jasa. Pekerja yang telah berkeluarga membutuhkan 53 macam barang dan jasaWaktu penelitian (bulan, triwulan, tahun).Harga barang, Pti adalah harga suatu jenis barang tertentu pada saat tertentu pulaJumlah satuan barang dan jasa yang diteliti, Qoi adalah jumlah barang atau jasa tertentu pada tahun dasar. Nilai $\mathrm{Q}$ untuk setiap barang dan jasa telah ditentukan terlebih dahulu jumlah minimumnya. Settiap tahun nilai $Q$ ini tetap untuk semua jenis barang dan jasa yang diperlukan.

Dalam perkembangannya pengukuran KFM sendiri kemudian direvisi pada 1996 oleh Dewan Pengupahan Nasional dengan membuat sebuah paket konsumsi yang lebih luas baik secara kualitas maupun kuantitas dan dikenal dengan Kebutuhan Hidup Minimum(KHM) dalam rangka untuk meningkatkan standar hidup pekerja. Beberapa komponen juga ditambahkan seperti komponen pendidikan dan rekreasi. Berdasarkan kebijakan Menteri Tenaga Kerja No 61/1995, KHM diukur oleh paket konsumsi yang detail yang terdiri dari 43 jenis barang, dimana termasuk didalamnya 11 jenis barang dalam kelompok makanan, 19 jenis dalam kelompok perumahan, 8 jenis dalam kelompok pakaian, 5 jenis termasuk dalam kelompok yang lain, yang mana meningkat $15 \%$ sampai $20 \%$ lebih dari KFM dalam rupiah.

Secara umum tingkat upah minimum di Indonesia ditetapkan pada level propinsi. Sebelum otonomi daerah pemerintah pusat (dalam hal ini Kementrian Tenaga Kerja) menetapkan tingkat upah minimum setiap propinsi didasarkan pada rekomendasi dari pemerintah daerah (propinsi), sedangkan setelah otonomi daerah (setelah tahun 2001), pemerintah daerah memiliki kebebasan dalam menentukan tingkat upah minimumnya. Sebelum otonomi daerah, propinsi secara umum hanya memiliki satu tingkat upah minimum dan berlaku untuk seluruh wilayah kota/kabupaten, sedangkan setelah otonomi daerah, setiap kota/kabupaten diberi kebebasan untuk menentukan tingkat upah minimumnya sepanjang tidak berada di bawah tingkat upah minimum propinsi. Di beberapa kasus, tingkat upah minimum juga dibedakan berdasarkan sektor aktivitasnya. Dalam prakteknya, empat propinsi di Jawa dan Bali (Jawa Barat, Jawa Tengah, Jawa Timur, dan Bali) memiliki tingkat upah minimum kota/kabupaten sedangkan daerah diluar Jawa cenderung untuk menentukan tingkat upah minimum propinsi bagi setiap wilayah kota/kabupatennya.

\section{Penetapan Upah Minimum Setelah Otonomi Daerah}

Sejak tahun 2001, sebagai bagian dari perubahan regim politik dari sentralisasi menjadi desentralisasi, kewenangan penetapan tingkat upah minimum juga dipindahkan kepada tingkat propinsi dan kota/kabupaten yang mana bekerja sama dengan komisi upah pada tingkat daerah. Setiap komisi upah terdiri dari perwakilan dari dinas ketenagakerjaan, pengusaha, perwakilan 
serikat pekerja dan beberapa penasehat ahli dari perguruan tinggi (Manning, 2003a). Adapun tujuan utama dari kebijakan desentralisasi ini adalah untuk meningkatkan efektivitas ekonomi, efisiensi, dan persamaan akses terhadap public services (Sugiyarto dan Endriga, 2008). SMERU (2003) juga berpendapat bahwa desentralisasi kewenangan ke level pemertintahan yang lebih rendah dalam penetapan UMR juga bertujuan untuk membagi resiko dalam bernegosiasi dengan serikat pekerja di setiap daerah, seperti misalnya demonstrasi besar ketika upah minimum naik atau berubah. Lebih lanjut, pemerintah daerah juga dianggap lebih mengerti tentang masalah dan kondisi ketenagakerjaan daerahnya dibandingkan pemerintah pusat sehingga desentralisasi adalah mutlak untuk harus dilakukan.

Berdasarkan peraturan pemerintah, pemerintah daerah pada tingkat propinsi menetapkan upah minimum untuk setiap wilayah daerahnya, sedangkan kota/kabupaten memiliki pilihan untuk mengikuti atau menetapkan upah minimum diatas tingkat upah minimum propinsi tetapi tidak berada di bawahn upah minimum propinsi (UMP). Seperti yang ditegaskan oleh Manning (2003a), pelaksanaannya cukup bervariasi antar propinsi. Beberapa propinsi seperti DKI Jakarta dan banyak propinsi di luar Jawa tetap menggunakan UMP untuk upah minimum daerahnya. Disisi yang lain beberapa propinsi seperti Jawa Barat, Jawa Tengah, Jawa Timur dan Bali memilih untuk memiliki upah minimum pada tingkat kota/kabupaten.

Berdasarkan peraturan pemerintah, dalam menentukan tingkat upah minimum beberapa komponen pertimbangannya adalah:

(a) biaya Kebutuhan Hidup Minimum (KHM)

(b) indeks harga konsumen (IHK)

(c) kemampuan, pertumbuhan dan, keberlangsungan dari perusahaan

(d) tingkat upah minimum antar daerah

(e) kondisi pasar kerja

(f) pertumbuhan ekonomi dan pendapatan per kapita

Pemindahan kewenangan dalam penetapan tingkat UMR kepada pemerintah kota/ kabupaten dalam era otonomi daerah ini memiliki dampak yang besar terhadap trend upah minimum. Ditambah lagi dengan adanya tekanan dari pekerja di daerah dan semakin kuatnya serikat pekerja pada level regional memiliki pengaruh yang signifikan terhadap kenaikan upah minimum di banyak propinsi di Indonesia. Secara rata-rata misalnya tingkat upah nominal telah meningkat 30\% per tahun pada 2001 dan 2002 (Suryahadi dkk, 2003). Bahkan beberapa kasus di daerah menunjukkan bahwa kenaikan upah minimum telah jauh berada diatas kenaikan inflasi daerah, seperti contohnya di Jawa Barat dan Jawa Timur (Manning, 2003a).

Meskipun kenaikan ini secara umum berdasarkan pada kenaikan dari Kebutuhan Hidup Minimum, semua ini terjadi pada saat pertumbuhan ekonomi yang relatif rendah yaitu setelah periode krisis ekonomi 1997-1998. Dibandingkan dengan negara Asia lainnya yang memiliki tingkat pembangunan yang hampir sama maka tingkat upah minimum rata rata di Indonesia hanya lebih rendah daripada upah minimum di Filipina dan Thailand, tetapi secara relatif lebih tinggi daripada upah minimum di Vietnam, Kamboja, Sri Lanka, Pakistan dan Bangladesh (Manning, 2003a). 


\section{Analisis tentang Kebijakan Upah Minimum di Indonesia dalam kaitannya dengan Pekerjaan atau Penghidupan yang Layak (Pasal 27 ayat 2 UUD 45)}

Dalam penentuan upah minimum pada suatu daerah terdapat beberapa hal yang patut dikaitkan dengan UUD 45 terutama dalam usaha untuk mendapatkan pekerjaan atau penghidupan yang layak.

\section{Kebutuhan Hidup Layak sebagai Komponen Penentuan Upah Minimum}

Penggunaan Kebutuhan Hidup Layak (KHL) dalam komponen dalam penentuan upah minimum sejah tahun 2005 sudah barang tentu merupakan sinyal yang baik dalam peningkatan kesejahteraan pekerja, terutama setelah sebelumnya hanya menggunakan Kebutuhan Hidup Minimum (KHM). Meskipun demikian apabila dilihat pada 4.2. masih banyak daerah yang masih belum memenuhi upah minimum di daerah sebesar KHL. Hal ini bisa dilihat dari rata-rata rasio upah minimum terhadap KHL yang hanya sebesar $84 \%$ atau dengan kata lain masih cukup berada jauh dibawah KHL, meskipun di beberapa daerah sudah berada diatas kebutuhan hidup layak.

Untuk itu perlu terus diusahakan agar KHL tetap menjadi komponen utama dalam penentuan upah minimum tanpa mengesampingkan komponen-komponen yang lain seperti IHK, PDRB, dan keberlangsungan perusahaan. Bargaining-bargaining antar tripartite dalam penentuan upah minimum di daerah juga harus selalu diarahkan untuk pemenuhan kebutuhan hidup layak dari pekerja.

Meskipun demikian, sayangnya masih belum ada pedoman yang jelas dan detail tentang bagaimana kritria criteria dari KHL dikumpulkan antar daerah. Sebagai contoh dalam penentuan biaya KHM, penaksiran beragam antar daerah tergantung pada tipe dari pasar yang dikunjungi dan kualitas dan kemampuan dari komisi upah (Manning, 2003a). Sebagai tambahan, di beberapa daerah, beberapa data selain komponen KHL juga masih dirasakan sangat terbatas, seperti IHK dan kemampuan perusahaan.

\section{Transparansi dan Sosialisasi Pemberian Tunjangan dalam Upah Minimum}

Menurut peraturan pemerintah, Upah minimum adalah terdiri dari upah pokok dan tunjangan tetap. Namun sayangnya dalam peraturan pemerintah yang diatur secara jelas hanya upah pokoknya saja dan tidak termasuk tunjangan, sehingga seringkali menimbulkan kontroversi bagi pengusaha dan pekerja. Hal ini menimbulkan perbedaan pemahaman tentang arti tunjangan baik bagi pengusaha maupun pekerja. Tunjangan tetap sendiri sebenarnya adalah tunjangan yang diberikan secara tetap tanpa melihat tingkat kehadiran pekerja ataupun output, seperi misalnya tunjangan keluarga tetap dan tunjangan yang berdasar pada senioritas.

Sosialisasi tentang hal ini juga dirasa masih kurang. Survey dari SMERU (2003) misalkan menyebutkan bahwa masih banyak sekali pekerja tidak mengetahui komponen upah minimum mereka secara detail. Bahkan banyak pula pekerja yang hanya mendapatkan upah tetap tanpa mendapatkan tunjangan sebagai komponen upah minimumnya, dan ini tanpa sepengetahuan pekerja dikarenakan ketidaktahuan mereka tentang komponen dalam upah minimum yang harusnya meliputi tunjangan tetap. 


\section{Status Pekerja yang dilindungi dalam Kebijakan Upah Minimum}

Dalam peraturan pemerintah sebenarnya seluruh pekerja yang bekerja dan menerima upah termasuk didalam yang dilindungi kebijakan upah minimum. Namun pada kenyataannya, kebijakan upah minimum kebanyakan hanya berlaku untuk pekerja tetap bulanan di usaha-usaha menengah dan besar. Survei SMERU (2003) menunjukkan bahwa masih banyak sekali pekerja lepas harian dan pekerja borongan yang tidak dilindungi oleh kebijakan upah minimum. Dalam hal ini dibutuhkan sebuah pedoman yang jelas tentang bagaimana kebijakan upah minimum diterapkan terutama untuk pekerja yang sifatnya harian lepas atau borongan. Selain itu perlu dipikirkan juga bagaimana kebijakan upah minimum ini bisa diterapkan untuk pekerja di usaha skala mikro dan kecil dimana untuk Indonesia skala mikro dan kecil cukup mendominasi dibandingkan skala menengah dan besar.

Selain itu, kebijakan upah minimum hanya ditujukan bagi pekerja bagi sektor formal, sedangkan pekerja di Indonesia lebih dari $60 \%$ nya adalah pekerja pada sektor informal. Sehingga tentunya selain kesejahteraan pekerja pada sektor formal dibutuhkan sebuah kebijakan yang juga dapat meningkatkan kesejahteraan pekerja. Ditambah lagi dengan teori dual sektor yang menyatakan bahwa kenaikan upah minimum dapat menggeser atau memindah pekerja dari sektor formal ke sektor informal.

\section{Penegakan dan Pemberian Sanksi yang tegas bagi Perusahaan yang tidak Menerapkan Kebijakan Upah Minimum}

Untuk menjamin pelaksanaan kebijakan upah minimum yang dapat meningkatkan kesejahteraan bagi pekerja maka diperlukan penegakan dan sanksi yang tegas bagi pengusaha yang tidak menerapkan kebijakan upah minimum. Sampai saat ini memang belum dirumuskan sebuah sanksi yang efektif bagi perusahaan yang terus-menerus membayar pekerja mereka dibawah tingkat upah minimum. Survei dari SMERU (2003) menunjukkan bahwa pemerintah masih banyak mentolerir perusahaan yang membayar dibawah upah minimum untuk menghindari PHK yang besar oleh perusahaan. Sebuah femonena yang dilematis yang sebenarnya harus dapat diselesaikan oleh pihak pengusaha dan pekerja dengan tentu bantuan dari pemerintah untuk menentukan rule of the game kebijakan upah minimum ini sendiri.

\section{E. KESIMPULAN DAN REKOMENDASI}

\section{Kesimpulan}

Sesuai dengan rumusan masalah dan hasil pembahasan diatas, ada beberap poin penting yang dapat disimpulkan sebagai berikut

1. Kebijakan upah minimum telah mengalami berbagai perubahan baik sebelum maupun setelah otonomi daerah. Sebelum otonomi daerah pemerintah pusat menetapkan tingkat upah minimum setiap propinsi didasarkan pada rekomendasi dari pemerintah daerah (propinsi). Sedangkan setelah otonomi daerah yang diimplementasikan pada tahun 2001 , pemerintah daerah memiliki kebebasan dalam menentukan tingkat upah minimumnya. Sebelum otonomi 
daerah, propinsi secara umum hanya memiliki satu tingkat upah minimum dan berlaku untuk seluruh wilayah kota/kabupaten, namun setelah otonomi daerah, setiap kota/kabupaten diberi kebebasan untuk menentukan tingkat upah minimumnya sepanjang tidak berada di bawah tingkat upah minimum propinsi.

2. Pelaksanaan kebijakan upah minimum sesuai dengan UUD 1945 pasal 27 ayat 2 tentang penghidupan yang layak, setidaknya harus memuat beberapa hal yang harus dilakukan. Hal tersebut diantaranya adalah memasukan kebutuhan hidup layak sebagai komponen penentuan upah minimum. Selanjutnya diperlukannya suatu upaya yang transparan dan sosialisasi secara intens mengenai pemberian tunjangan dalam upah minimum. Selain itu harus adanya kejelasan mengenai status pekerja yang dilindungi dalam kebijakan upah minimum. Terakhir adalah penegakan dan pemberian sanksi yang tegas bagi perusahaan yang tidak menerapkan kebijakan upah minimum yang sesuai.

\section{Rekomendasi}

Sesuai dengan hasil pembahasan pada bab sebelumnya, beberapa rekomendasi yang harus dilakukan oleh pemerintah dalam upaya mengimplementasikan kebijakan upah minimum yang sesuai dengan UUD 1945 pasal 27 ayat 2 sebagai berikut.

1. Diperlukannya mereformulasi kebijakan upah minimu yang ada disesuaikan dengan UUD 1945 diantaranya adalah memasukan komponen kebutuhan hidup layak dalam penentuan upah minimum.

2. Diperlukannya UU dan peraturan pemerintah baik pusat maupun daerah yang mengatur secara teknis petunjuk penetapan upah minimum yang manusiawi

3. Perlunya sosialisasi secara intens mengenai pemberian tunjangan dalam upah minimum.

4. Harus adanya kejelasan mengenai status pekerja yang dilindungi dalam kebijakan upah minimum.

5. Perlunya penegakan dan pemberian sanksi yang tegas bagi perusahaan yang tidak menerapkan kebijakan upah minimum yang sesuai.

\section{DAFTAR PUSTAKA}

Abowd, J. M., Kramarz, F., Lemieux, T. And Margolis, D. N. (1997), "Minimum Wages and Youth Employment in France and the United States". NBER Working Paper No. 6111, National Bureau of Economic Research, Cambridge, Mass., USA.

Agrawal, N. (1995), "Indonesia: Labor Market Policies and International Competitiveness". World Bank Policy Research Working Paper No. 1515.

Ahmed, I. and Dhanani, S. (1999), “Indonesia's Recovery: Employment Optimism or Statistical Illusion?”. Occasional Discussion Paper Series No. 2, International Labour Office, Jakarta,

Card, D. (1992a), "Do Minimum Wages Reduce Employment?: ACase Study of California, 19871989”. Industrial and Labor Relations Review, 46(1), 38-54.

Card, D. (1992b), "Using Regional Variation in Wages to Measure the Effects of the Federal Minimum Wages". Industrial and Labor Relations Review, 46(1), 22-37. 
Card, D. And Krueger, A. (1994), "Minimum Wages and Employment: A Case Study of the Fast Food Industry in New Jersey and Pennsylvania". The American Economic Review, 84(4), 772-793.

Card, D. And Krueger, A. (1995), Myth and Measurement: The New Economics of the Minimum Wage. Princeton, New Jersey: Princeton University Press.

Card, D., Katz, L. And Krueger, A (1994), "Comment on David Neumark and William Wascher, Employment Effects of Minimum and Subminimum Wages: Panel Data on State Minimum Wage Laws". Industrial and Labor Relations Review, 47(3), 487-496.

Feridhanusetyawan, T. And Damuri, Y. R. (2004), "Economic Crisis and Trade Liberalization: A CGE Analysis on The Forestry Sector". CSIS Working Paper No. WPE 079.

Feridhanusetyawan, T. And Gaduh, A. B. (2000), “Indonesia's Labor Market During the Crisis: Empirical Evidence from Sakernas 1997-1999". The Indonesian Quarterly, 28(3), 295-315.

Flippo, Edwin B, 1984, Manajemen Personalia, Jilid 2, Edisi Keenam, Terjemahan M. Masud, Erlangga, Jakarta.

Gall, G. (1998), “The Development of the Indonesian Labour Movement”. International Journal of Human Resources Management, 9(2), 359-376.

Gindling, T. H. And Terrell, K. (2005), "The Effect of Minimum Wages on Actual Wages in Formal and Informal Sectors in Costa Rica”. World Development, 33(11), 1905-1921.

Gindling, T. H. And Terrell, K. (2006), "Minimum Wages and the Welfare of Different Types of Workes in Honduras". Working Paper, University of Maryland.

Manning, C. (2000), "Labour Market Adjustment to Indonesia’s Economic Crisis: Context, Trends, and Implications". Bulletin of Indonesian Economic Studies, 36(1), 105-136.

Manning, C. (2003a), “Labor Policy and Employment Creation: An Emerging Crisis?”. PEG-USAID, Technical Report.

Manning, C. (2003b), Monopsony in Motion. Princeton: Princeton University Press.

Payaman Simanjuntak J, 1998, Pengantar Ekonomi Sumber Daya Manusia, Edisi Kedua, Lembaga Penerbit Fakultas Ekonomi UI, Jakarta.

Rama, M. (2001), "The Consequences of Doubling the Minimum Wage: The Case of Indonesia". Industrial and Labor Relations Review, 54(4), 864-881.

Rooney, P. And Anggriani, N. (2006), “The Impact of Formal and Informal Labor Regulations in Business in Serang District", Technical Report, World Bank Jakarta.

SMERU (2003), "Penerapan Upah Minimum di Jabotabek dan Bandung”. Technical Report.

Suryahadi, A., Widyanti, W., Perwira, D. And Sumarto, S. (2001), "Wage and Employment Effects of Minimum Wage Policy in the Indonesian Urban Labour Market”. Working Paper, SMERU.

Suryahadi, A., Widyanti, W., Perwira, D., Sumarto, S. (2003), "Minimum Wage Policy and Its Impact on Employment in the Urban Formal Sector". Bulletin of Indonesian Economic Studies, 39(1), 29-50. 